\title{
Behavior of indirect maximal oxygen uptake on users of the PROSA Program at Universidad de Antioquia, Medellín, Colombia
}

\author{
Jorge Jaime Márquez, MD¹, Gildardo Díaz, Lic², Cristiam Paul Tejada, Lic ${ }^{3}$
}

\section{SUMMARY}

Objective: This research work sought to describe the behavior of maximal oxygen uptake $\left(\mathrm{VO}_{2 \max }\right)$ in a population of adults who performed regular physical activity and classify the level of cardio-respiratory fitness.

Methods: 819 results were analyzed with the estimated 2000-m $\mathrm{VO}_{2 \max }$ test from 2001 to 2009 of 125 subjects who exercise regularly in the PROSA program at Universidad de Antioquia and were discriminated by decade and gender.

Results: The results showed that $\mathrm{VO}_{2 \max }$ reached its peak between 30 and 39 years of age in men $(52.0 \pm 2.5 \mathrm{ml} * \mathrm{~kg}-1$ * min- 1$)$ and women $(42.9 \pm 3.5 \mathrm{ml} * \mathrm{~kg}-1 * \min -1)$. There were significant differences between the $\mathrm{VO}_{2 \max }$ of men and women and the decline in all age groups, except for those over 70 years of age. The $\mathrm{VO}_{2 \max }$ of men in the study was maintained between the 70 and 90 percentiles, while that of women was between 70 and 80 percentiles.

Conclusion: The decline in $\mathrm{VO}_{2 \max }$ associated with age is different for men and women and it is different in almost all age groups

Keywords: Maximal oxygen uptake; Cardio-respiratory fitness; Aging.

Colomb Med. 2011; 42: 327-33

Comportamiento del consumo máximo de oxígeno indirecto en los usuarios del Programa PROSA de la Universidad de Antioquia, Medellín, Colombia

\section{RESUMEN}

Objetivo: Describir el comportamiento del consumo máximo de oxígeno $\left(\mathrm{VO}_{2 \mathrm{Máx}}\right)$ en una población de adultos que realiza actividad física regular y clasificar el nivel de fitness cardiorrespiratorio.

Métodos: Se analizaron 819 resultados del $\mathrm{VO}_{2 \mathrm{Max}}$ estimado con la prueba de 2000 metros entre los años 2001 a 2009 de 125 sujetos que realizan ejercicio físico regular en el Programa PROSA de la Universidad de Antioquia y se discriminaron por década y sexo.

Resultados: Se mostró que el $\mathrm{VO}_{2 \text { Máx }}$ alcanzó su pico máximo entre las edades de 30 a 39 años en hombres $\left(52 \pm 2.5 \mathrm{ml} * \mathrm{~kg}^{-}\right.$ $1 * \mathrm{~min}^{-1}$ ) y mujeres $\left(42.9 \pm 3.5 \mathrm{ml}^{*} \mathrm{~kg}^{-1 *} \mathrm{~min}^{-1}\right)$. Se encontraron diferencias significativas entre el $\mathrm{VO}_{2 \text { Máx }}$ de hombres y mujeres $\mathrm{y}$ en la disminución en todos los grupos etarios, excepto en los mayores de 70 años. $\mathrm{El}^{\mathrm{VO}_{2 \mathrm{Máx}}}$ de los hombres del estudio se mantiene entre los percentiles 70 y 90 ; el de las mujeres entre los percentiles 70 y 80 .

Conclusión: La disminución del $\mathrm{VO}_{2 \text { Máx }}$ asociada con la edad es diferente para hombres y mujeres y también en casi todos los grupos etarios.

Palabras clave: Consumo máximo de oxígeno; Fitness cardiorrespiratorio; Envejecimiento.

Colomb Med. 2011; 42: 327-33

1. Professor, University Institute of Physical Education, Universidad de Antioquia, GRICAFDE Group, Medellín, Colombia. e-mail: jaimejorge33@yahoo.com

2. Professor of Physical Education, Universidad de Antioquia, GRICAFDE Group, Medellín, Colombia. e-mail: coorprosa@gmail.com

3. Professor of Physical Education, Popular Sports Schools Program, INDER, Medellín, Colombia. GRICAFDE Group. e-mail: cristejada2002@yahoo.es

Received for publication October 23, 2009 Accepted for publication April 24, 2010 
There is sufficient evidence to support that levels of cardio-respiratory fitness are inversely associated with all-cause mortality, heart disease, cancer, and other chronic diseases and that cardio-respiratory fitness is related to health, independence, and functional capacity $^{1-4}$ and there is interest in the investigation of the decline in age-related $\mathrm{VO}_{2 \max }{ }^{5}$; although there are differences in the studies, these generally reported a decrease of $0.4-0.5 \mathrm{ml} / \mathrm{kg} / \mathrm{min} /$ year $(9 \%-10 \%$ per decade) for men and women, regardless of the level of activity $^{5,6}$. High-intensity regular exercise can reduce this loss to $50 \%$ in young or middle-aged men but not in older adults; women do not seem to be able to reduce it to less than $10 \%$ per decade. The loss of age-related $\mathrm{VO}_{2 \max }$ appears to occur non-linearly in association with decreased physical activity. In sedentary individuals, this occurs between 20 and 30 years of age, and in athletes after reducing or completing training 5 .

Measuring or estimating $\mathrm{VO}_{2 \max }$ can be performed with direct and indirect standardized assessments ${ }^{7,8}$. Direct assessments are those that measure $\mathrm{VO}_{2 \max }$ and other physiological variables by using, for example, respiratory gas analyzers. Indirect assessments are those designed to estimate $\mathrm{VO}_{2 \max }$ without the need for special equipment and are based on equations with variables such as gender, age, height, weight, and distance traveled and can be performed on a running track, a treadmill, etc.; these include the Cooper test, Balke test, the Rockport 1-mile test, 1.5-mile running test, and the 2000-m Ukk test ${ }^{9}$.

In our environment, we know of no published research on the subject and because of the variability of results, the aim of this study was to describe the behavior of maximal oxygen intake in a population of adults who perform regular physical activity and secondarily, to classify the level of cardio-respiratory fitness.

\section{MATERIALS AND METHODS}

This descriptive study was conducted by reviewing digital records from the 2000-meter Test of PROSA program users from 2001-2009.

PROSA is the psychophysical health program of Universidad de Antioquia and it employs physical activity and exercise as a means for disease prevention and health promotion. It is directed to employees, teachers, and retirees of Universidad de Antioquia, regardless of gender and age. The program works year round, with a frequency of 5 days per week and with a 1-h duration per session. The 380 individuals are divided into 13 groups who exercise mornings, noon, and evenings. Each of the users participating in the program has a sports medical follow-up seeking to prescribe and monitor exercise (the execution and exercise prescription is to be individualized and follow the American College of Sports Medicine (ACSM) recommendations $)^{6}$.

Secondary sources were used (digital records) of 125 subjects intentionally selected from a total population of 380 individuals. Subjects who had at least three assessments of indirect maximal oxygen intake between 2001 and 2009 were considered as inclusion criterion. We excluded subjects who had less than three assessments to consider only people who have had greater participation in the program.

Estimation of $\boldsymbol{V} \boldsymbol{O}_{2 \max }$. To estimate the indirect maximal oxygen uptake of users of the PROSA program, we calculated the time spent in the 2000 -m test by using the following parameters: For individuals who can only perform the test by walking, we consider the following variables and formulas, respectively: time: duration of the run in minutes and seconds; heart rate: at the end of the test (in beats per minute); body mass index (BMI): (weight divided by the square of height in meters); age: years old; $\mathrm{VO} 2_{\max }=84.9-4.65 *$ time- $0.22 *$ heart rate $-0.26 *$ age-1.05* BMI (for men). $\mathrm{VO}_{2 \max }=116.2-2.98$ * time- $0.11 *$ heart rate- $0.14 *$ age- $0.39 *$ BMI (for women). For individuals who take the test by jogging, we have accounted the time spent in minutes and seconds and used the following formula: $\mathrm{VO}_{2 \max }=11.6$ $+0.176 *(2000 /$ time $)$.

Statistical analysis. For statistical analysis, data collected from digital files were entered into the Excel ${ }^{\circledR}$ spreadsheet and we calculated the mean, standard deviation, and coefficient of variation. $\mathrm{VO}_{2 \max }$ data were grouped into 10-year intervals in both men and women, and were placed into percentiles and compared with ACSM reference tables (Table 1 and 2) ${ }^{6}$. We also applied the Student $t$ test to establish significant differences between the values of $\mathrm{VO}_{2 \max }$ for men and women, as well as by age groups. ANOVA was applied and a Tukey test was applied to determine significant differences between age groups of men and between age groups of women. 
Table 1

$\mathrm{VO}_{2 \max }(\mathrm{ml} / \mathrm{kg} / \mathrm{min})$ in male non-athletes, according to American College of Sports Medicine

\begin{tabular}{cccccc}
\hline Percentile & \multicolumn{5}{c}{ Age (years) } \\
\cline { 2 - 6 } & $\mathbf{2 0 - 2 9}$ & $\mathbf{3 0 - 3 9}$ & $\mathbf{4 0 - 4 9}$ & $\mathbf{5 0 - 5 9}$ & $\geq \mathbf{6 0}$ \\
\hline 90 & 55.1 & 52.1 & 50.6 & 49.0 & 44.2 \\
80 & 52.1 & 50.6 & 49.0 & 44.2 & 41.0 \\
70 & 49.0 & 47.4 & 45.8 & 41.0 & 37.8 \\
60 & 47.4 & 44.2 & 44.2 & 39.4 & 36.2 \\
50 & 44.2 & 42.6 & 41.0 & 37.8 & 34.6 \\
40 & 42.6 & 41.0 & 39.4 & 36.2 & 33.0 \\
30 & 41.0 & 39.4 & 36.2 & 34.2 & 31.4 \\
20 & 37.8 & 36.2 & 34.6 & 31.4 & 28.3 \\
10 & 34.6 & 33.0 & 31.4 & 29.9 & 26.7 \\
\hline
\end{tabular}

Table 2

$\mathrm{VO}_{2 \max }(\mathrm{ml} / \mathrm{kg} / \mathrm{min})$ in women non-athletes, according to American College of Sports Medicine

\begin{tabular}{cccccc}
\hline Percentile & \multicolumn{5}{c}{ Age (years) } \\
\cline { 2 - 6 } & $\mathbf{2 0 - 2 9}$ & $\mathbf{3 0 - 3 9}$ & $\mathbf{4 0 - 4 9}$ & $\mathbf{5 0 - 5 9}$ & $\geq \mathbf{6 0}$ \\
\hline 90 & 49.0 & 45.8 & 42.6 & 37.8 & 34.6 \\
80 & 44.2 & 41.0 & 39.4 & 34.6 & 33.0 \\
70 & 41.0 & 39.4 & 36.2 & 33.0 & 31.4 \\
60 & 39.4 & 36.2 & 34.6 & 31.4 & 28.3 \\
50 & 37.8 & 34.6 & 33.0 & 29.9 & 26.7 \\
40 & 36.2 & 33.0 & 31.4 & 28.3 & 25.1 \\
30 & 33.0 & 31.4 & 29.9 & 26.7 & 23.5 \\
20 & 31.4 & 29.9 & 28.3 & 25.1 & 21.9 \\
10 & 28.3 & 26.7 & 25.1 & 21.9 & 20.3 \\
\hline
\end{tabular}

\section{RESULTS}

We analyzed the records of the 2000-m test of 125 subjects, 50 men (40\%) and 75 women $(60 \%)$ with mean age of $57.7 \pm 9.1$ years and $54.7 \pm 11.6$ years, respectively.

Table 3 shows the number of follow-up evaluations conducted between 2001 and 2009. It is noted that subjects with $6,7,8$, and 9 assessments represent $73 \%$ of the study population.

In whole, we analyzed 819 data of $\mathrm{VO}_{2 \max }, 338$ (41.3\%) from men and $481(58.7 \%)$ from women. Table 4 adds the evaluations between 2001 and 2009. It is observed that between 50 and 59 years of age, 305 evaluations were analyzed for men and women.

Table 5 presents changes in $\mathrm{VO}_{2 \max }$ with age in men and women. It is noted that the best average was between 30 and 39 years for both men $(52 \mathrm{ml} * \mathrm{~kg}-1 *$ min-1) and women (49.2 ml* kg-1* min-1); thereafter, there is a decrease of $\mathrm{VO}_{2 \max }$. Significant differences were found between maximal oxygen uptake for men and women and there were also differences between age groups, except for those older than 70 years of age $(\mathrm{p}=0.30)$.

According to the results presented in Table 6 , in the group of men there are significant differences from 40 years of age; in that of women, although differences existed between 30 and 40 years of age, the differences 
Table 3

Number of evaluations per subject between 2001 and 2009

\begin{tabular}{|c|c|c|c|}
\hline \multicolumn{2}{|c|}{$\begin{array}{l}\text { Total assessments } \\
\text { between 2001-2009 }\end{array}$} & 9 & 7 \\
\hline \multicolumn{2}{|l|}{ Subjects } & 14 & 24 \\
\hline \multicolumn{2}{|l|}{ Population (\%) } & 1.2 & 19.2 \\
\hline \multicolumn{4}{|c|}{$\begin{array}{c}\text { Table } 4 \\
\text { Assessments of maximum oxygen uptake } \\
\text { between } 2001 \text { and } 2009\end{array}$} \\
\hline \multirow[b]{2}{*}{ Ages (years) } & \multicolumn{3}{|c|}{ Assessments } \\
\hline & Men & Women & $\begin{array}{l}\text { Percentage } \\
\text { by age }\end{array}$ \\
\hline$\geq 70$ & 20 & 33 & 6.5 \\
\hline $60-69$ & 72 & 100 & 21.0 \\
\hline $50-59$ & 150 & 155 & 37.2 \\
\hline $40-49$ & 82 & 125 & 25.3 \\
\hline $30-39$ & 14 & 50 & 7.8 \\
\hline$\leq 29$ & NA & 18 & 2.2 \\
\hline $\begin{array}{l}\text { Total } \\
\text { assessments }\end{array}$ & 338 & 481 & 819 \\
\hline $\begin{array}{l}\text { Percentage of } \\
\text { assessments }\end{array}$ & 41.3 & 58.7 & 100.0 \\
\hline
\end{tabular}

become more well-known and constant from 50 years of age.

Table 7 shows the $\mathrm{VO}_{2 \max }$ expressed in $\mathrm{ml} * \mathrm{~kg}$ 1 *min- 1 and Mets per decade in men and the location

\section{Assessments}

$\begin{array}{lllll}7 & 6 & 5 & 4 \text { and } 3 & \text { Total }\end{array}$

$24 \quad 26$

20.8

17
0

13.6

17

13.6

125

$100 \%$

Table 6

$p$ value for the Tukey test in the ANOVA procedure to compare age groups for men and women

\begin{tabular}{lcc}
\hline Age groups (years) & Men & Women \\
\hline$(30-39)-(40-49)$ & 0.99 & $0.02^{*}$ \\
$(40-49)-(50-59)$ & $0.00^{*}$ & 0.21 \\
$(50-59)-(60-69)$ & $0.00^{*}$ & $0.00^{*}$ \\
$(60-69)-(e » 70)$ & $0.00^{*}$ & $0.00^{*}$ \\
\hline
\end{tabular}

* significant, $p<0.05$

in percentiles according to the ACSM. It is noted that the average $\mathrm{VO}_{2 \max }$ with age in men is between the $70^{\text {th }}$ and $90^{\text {th }}$ percentiles. For men over 70 years of age, percentiles were not found because ASCM tables do not report accurate data for that age range.

Table 8 describes the $\mathrm{VO}_{2 \max }$ expressed in $\mathrm{ml} * \mathrm{~kg}$ $1 *$ min- 1 and at Mets per decade in women and their location in percentiles according to the ACSM. It is noted that the average $\mathrm{VO}_{2 \max }$ according to age in women is between the $70^{\text {th }}$ and $80^{\text {th }}$ percentiles.

Table 5

Mean maximum oxygen uptake by age group and gender

\begin{tabular}{lccccc}
\hline Age decade for men and women & $\mathbf{3 0 - 3 9}$ & $\mathbf{4 0 - 4 9}$ & $\mathbf{5 0 - 5 9}$ & $\mathbf{6 0 - 6 9}$ & $\mathbf{2 7 0}$ \\
\hline Average $\mathrm{VO}_{2 \max }$ in men & $52.0 \pm 2.5$ & $50.6 \pm 4.9$ & $44.8 \pm 7.0$ & $40.6 \pm 8.5$ & $31.3 \pm 6.5$ \\
Average $\mathrm{VO}_{2 \max }$ in women & $42.9 \pm 3.5$ & $39.0 \pm 5.1$ & $37.0 \pm 6.7$ & $31.8 \pm 7.3$ & $29.1 \pm 7.1$ \\
$\mathrm{~T}$ test among age groups & $0.00^{*}$ & $0.00^{*}$ & $0.00^{*}$ & $0.00^{*}$ & 0.30 \\
$\mathrm{~T}$ test between men and women & & & $0.00^{*}$ & & \\
\hline
\end{tabular}

$p$ value for Student $t$ to compare the data by gender in the same age range. *significant, $p<0.05 ; p$ value for Student $t$ to compare the data by gender regardless of age. * significant, $p<0.05$. 
Table 7 Location in $\mathrm{VO}_{2 \max }$ percentiles of men according to American College of Sports Medicine

\begin{tabular}{cccc}
\hline Age (years) & VO $_{2 \max }$ average $\left(\mathbf{m l}^{*} \mathbf{k g}^{-1 *} \mathbf{m i n}^{-1}\right)$ & Equivalence in Mets & Percentile according to ACSM \\
\hline $30-39$ & $52.0 \pm 2.5$ & 14.9 & 90 \\
$40-49$ & $50.6 \pm 4.9$ & 14.5 & 90 \\
$50-59$ & $44.8 \pm 7.0$ & 12.8 & 80 \\
$60-69$ & $40.6 \pm 8.5$ & 11.6 & 70 \\
$\geq 70$ & $31.3 \pm 6.5$ & 8.9 & $\mathrm{NA}$ \\
\hline
\end{tabular}

Table 8

Location in $\mathrm{VO}_{2 \max }$ percentiles of women according to American College of Sports Medicine

Age (years) $\mathrm{VO}_{2 \max }$ average $\left(\mathrm{ml}^{*} \mathrm{~kg}^{-1 *} \mathrm{~min}^{-1}\right) \quad$ Equivalence in Mets Percentile according to ACSM

\begin{tabular}{cccc}
\hline$\leq 29$ & $41.5 \pm 4.3$ & 11.9 & 70 \\
$30-39$ & $42.9 \pm 3.5$ & 12.3 & 80 \\
$40-49$ & $39.0 \pm 5.1$ & 11.1 & 70 \\
$50-59$ & $37.0 \pm 6.7$ & 10.6 & 80 \\
$60-69$ & $31.8 \pm 7.3$ & 9.1 & 70 \\
$\geq 70$ & $29.1 \pm 7.1$ & 8.3 & $\mathrm{NA}$ \\
\hline
\end{tabular}

\section{DISCUSSION}

This study describes changes in $\mathrm{VO}_{2 \max }$ associated with age over a period of nine years. The direct comparison with other cross-sectional or longitudinal studies is not the most accurate because there are differences in methodology and population, but, in general, in these, the trend is the decline of $\mathrm{VO}_{2 \max }$ with age in men and women $^{5,10-16}$ starting from 25 to 30 years of age, once physical maturity has been reached ${ }^{5,13,17}$.

There is controversy on the impact of physical activity in the rate of loss of aerobic power ${ }^{10,18,19,20,21}$. The meta-analysis of cross-sectional studies found no association between increased physical activity with decreased $\mathrm{VO}_{2 \max }{ }^{10,19}$, longitudinal studies suggest that regular vigorous exercise may slow to $50 \%$, but the reduction or suspension of training with the elderly may result in a misleading acceleration in that decline ${ }^{10}$; a study recently reported decreased $\mathrm{VO}_{2 \max }$ of $1 \%$ per annum after 25 years in subjects who do not perform physical activity and of $0.5 \%$ per annum for adult athletes; for other researchers, aerobic capacity declines $5-15 \%$ per decade ${ }^{5,17}$, an equivalent reduction of as much as $60 \%$ from 30 to 70 years of age; a recent review reported an average $5 \mathrm{ml} / \mathrm{kg} / \mathrm{min}$ per decade for all age groups and reported that progressive aerobic training can improve $\mathrm{VO}_{2 \max }$ at least $5-6 \mathrm{ml} / \mathrm{kg} / \mathrm{min}^{22}$ and others report that the annual rate of decline in $\mathrm{VO}_{2 \max }$ expressed in relative terms varies from 0.25 to $1.04 \mathrm{ml} / \mathrm{kg} / \mathrm{min}$, depending on gender and level of physical activity ${ }^{17}$.

In our study population, the decrease of $\mathrm{VO}_{2 \max }$ behaves indifferent form between every decade of life and significant differences between age groups exist $(p=0.00)$; therefore, it would be suitable to express the $\mathrm{VO}_{2 \max }$ and its decrease during the course of time, according to age groups in men and women.

Multiple studies suggest that age-associated decline is greater in men than in women when expressed in absolute terms such as 1 or $\mathrm{ml} / \mathrm{min}$, but when expressed perdecade, the apparent gender difference disappears ${ }^{10}$. Although cross-sectional studies show a linear decrease of $\mathrm{VO}_{2 \max }$ through life, a decline nonlinear acceleration of about $20 \%$ after 70 years of age was reported in longitudinal studies ${ }^{5,13,17}$.

In our study and in a longitudinal study ${ }^{13}$, the rate of decline in $\mathrm{VO}_{2 \max }$ varies among decades and has a 
considerable increase after 60 years of age. Also, there is an accelerated decrease per decade independent from the level of physical activity in men and women; comparatively, women have lower $\mathrm{VO}_{2 \max }$; this has also been reported in another study in individuals 60-92 years of age ${ }^{14}$.

For all the foregoing, it is proposed that the percentage or the annual change in $\mathrm{VO}_{2 \max }$ can not be generalized but expressed in terms of age and gender of the individuals.

$\mathrm{VO}_{2 \max }$ loss is due to central and peripheral adaptations ${ }^{5,17}$ and the decline in vigorous physical activity and age-related sarcopenia exacerbate the process ${ }^{13,17}$; related to these changes and to improve health, ACSM and other organizations recommend aerobic and strength training since early stages of life ${ }^{6}$.

Vigorous aerobic training can produce a $25 \%$ improvement of $\mathrm{VO}_{2 \max }(5-6 \mathrm{ml} / \mathrm{kg} / \mathrm{min})$ in the elderly, potentially delaying the loss of independence by 10 to 12 years $^{6,22}$. Controlled programs of regular exercise could contribute to the attenuation of the decline in agerelated $\mathrm{VO}_{2 \max }{ }^{6,14}$.

A recent meta-analysis ${ }^{23}$ reported that those with the best cardio-respiratory fitness $\left(\mathrm{VO}_{2 \max } \geq 7.9\right.$ Mets $v s$. $\mathrm{VO}_{2 \max } \leq 7.9$ Mets) is associated with lower risk of mortality from all causes and cardiovascular events in healthy men and women. The lowest level of $\mathrm{VO}_{2 \max }$ (8.3 Mets) $-70^{\text {th }}$ percentile- was for women over 70 years of age, but this value is classified as highly fitting into percentiles based on the location. This may mean they would get those benefits associated with the level of fitness and reduced risk of coronary heart disease, cancer, other chronic diseases, and better health and independence ${ }^{1-4,22,23}$.

Although a limitation of the study was measured by indirect $\mathrm{VO}_{2 \max }$ 2000-m UKK test, a 0.85 correlation was found with laboratory tests, along with a prediction error of $0.05 \mathrm{ml}^{*} \mathrm{~min}^{-1 *} \mathrm{~kg}^{-1}{ }^{24}$; similarly, the $2000-\mathrm{m}$ running test has a correlation of $0.71(\mathrm{p}<0.0001)$ with respect to ergospirometric evidence ${ }^{25}$. It should also be noted that the ACSM VO ${ }_{2 \max }$ data are from the United States population, but they are now the world reference ${ }^{6}$.

On the other hand, physical activity should ideally be assessed to stratify the groups and get more specific results from the age groups. Therefore, it would be important to perform prospective longitudinal studies that allow easily controlling multiple variables.

\section{CONCLUSIONS}

$\mathrm{VO}_{2 \max }$ had its peak in individuals between 30 and 39 years of age; in men it was $52 \pm 2.5 \mathrm{ml} * \mathrm{~kg}-1 *$ min1 and $42.9 \pm 3.5 \mathrm{ml} * \mathrm{~kg}-1 *$ min- 1 in women; thereafter, decreasing over the years. The decline in $\mathrm{VO}_{2 \max }$ associated with age is different for men and women and also different in almost all age groups.

In comparison with the ACSM tables, the population of individuals in the PROSA program remain at least at the $70^{\text {th }}$ percentile, therefore, their cardio-respiratory fitness $-\mathrm{VO}_{2 \max }$ - for age is high.

Conflict of interest. None of the authors has conflicts of interest related to this study.

\section{REFERENCES}

1. Laukkanen JA, Pukkala E, Rauramaa R, Mäkikallio TH, Toriola AT, Kurl S. Cardiorespiratory fitness, lifestyle factors and cancer risk and mortality in Finnish men. Eur J Cancer. 2010; 46: 355-63.

2. Prasad DS, Das BC. Physical inactivity: a cardiovascular risk factor. Indian J Med Sci. 2009; 63: 33-42.

3. Lavie CJ, Thomas RJ, Squires RW, Allison TG, Milani RV. Exercise training and cardiac rehabilitation in primary and secondary prevention of coronary heart disease. Mayo Clin Proc. 2009; 84: 373-83.

4. Nocon M, Hiemann T, Müller-Riemenschneider F, Thalau F, Roll S, Willich SN. Association of physical activity with allcause and cardiovascular mortality: a systematic review and meta-analysis. Eur J Cardiovasc Prev Rehabil. 2008; 15: 239-46.

5. Hawkins S, Wiswell R. Rate and mechanism of maximal oxygen consumption decline with aging: implications for exercise training. Sports Med. 2003; 33: 877-88.

6. American College of Sports Medicine. ACSM's Guidelines for Exercise Testing and Prescription. $7^{\mathrm{a}}$ ed. Philadelphia: Lippincott Williams \& Wilkins; 2006.

7. Reilly $\mathrm{T}$, Morris T, Whyte G. The specificity of training prescription and physiological assessment: a review. J Sports Sci. 2009; 27: 575-89.

8. Arboleda S. Convalidación de pruebas y ecuaciones predictivas para la estimación de la capacidad aeróbica: una necesidad del medio colombiano. Actividad física y desarrollo humano. 2006; 3: 65-80.

9. Pérez M. Pruebas funcionales de valoración aeróbica. En: López J. Fisiología del ejercicio. $3^{\mathrm{a}}$ ed. Madrid: Médica Panamericana; 2006. p. 442-70.

10. Zoeller RJ. Gender differences in cardiorespiratory fitness with advancing age: is the age-associated decline in $\mathrm{VO}_{2} \max$ more rapid in men and do older men and women respond differently to exercise? Am J Lifestyle Med. 2008; 2: 492-9.

11. Stathokostas L, Jacob-Johnson S, Petrella RJ, Paterson DH. Longitudinal changes in aerobic power in older men and 


\section{Colombia Médica}

women. J Appl Physiol. 2004; 97: 781-9.

12. Hollenberg M, Yang J, Haight TJ, Tager IB. Longitudinal changes in aerobic capacity: implications for concepts of aging. J Gerontol A Biol Sci Med Sci. 2006; 61: 851-8.

13. Fleg JL, Morrell CH, Bos AG, Brant LJ, Talbot LA, Wright $\mathrm{JG}$, et al. Accelerated longitudinal decline of aerobic capacity in healthy older adults. Circulation. 2005; 112: 674-82.

14. Weiss EP, Spina RJ, Holloszy JO, Ehsani AA. Gender differences in the decline in aerobic capacity and its physiological determinants during the later decades of life. $J$ Appl Physiol. 2006; 101: 938-44.

15. Paterson DH, Govindasamy D, Vidmar M, Cunningham DA, Koval JJ. Longitudinal study of determinants of dependence in an elderly population. J Am Geriatr Soc. 2004; 52: 1632-8.

16. Eskurza I, Donato AJ, Moreau KL, Seals DR, Tanaka H. Changes in maximal aerobic capacity with age in endurancetrained women: 7-yr follow-up. J Appl Physiol. 2002; 92: 2303-8.

17. Kenny GP, Yardley JE, Martineau L, Jay O. Physical work capacity in older adults: implications for the aging worker. $\mathrm{Am}$ $J$ Ind Med. 2008; 51: 610-25.

18. Pimentel AE, Gentile CL, Tanaka H, Seals DR, Gates PE. Greater rate of decline in maximal aerobic capacity with age in endurance-trained than in sedentary men. J Appl Physiol. 2003; 94: 2406-13.
Vol. 42 № 3, 2011 (Julio-Septiembre)

19. Wilson TM, Tanaka H. Meta-analysis of the age-associated decline in maximal aerobic capacity in men: relation to training status. Am J Physiol Heart Circ Physiol. 2000; 278: H829-34.

20. Fitzgerald MD, Tanaka H, Tran ZV, Seals DR. Age-related declines in maximal aerobic capacity in regularly exercising vs. sedentary women: a meta-analysis. J Appl Physiol. 1997; 83: $160-5$.

21. Tanaka H, Desouza CA, Jones PP, Stevenson ET, Davy KP, Seals DR. Greater rate of decline in maximal aerobic capacity with age in physically active vs. sedentary healthy women. $J$ Appl Physiol. 1997; 83: 1947-53.

22. Shephard RJ. Maximal oxygen intake and independence in old age. Br J Sports Med. 2009; 43: 342-6

23. Kodama S, Saito K, Tanaka S, Maki M, Yachi Y, Asumi M, et al. Cardiorespiratory fitness as a quantitative predictor of all-cause mortality and cardiovascular events in healthy men and women: a meta-analysis. JAMA. 2009; 301: 2024-35.

24. Zakariás G, Petrekanits M, Laukkanen R. Validity of a 2-km Walk Test in predicting the maximal oxygen uptake in moderately active Hungarian men. Euro J Sport Sci. 2003; 3: $1-8$

25. Díaz D, Valbuena L, Pérez J, Cardona, O. Correlación entre la ergoespirometria y la prueba de los 2000 metros. Rev Ant Med Dep. 2000; 3: 17-20. 